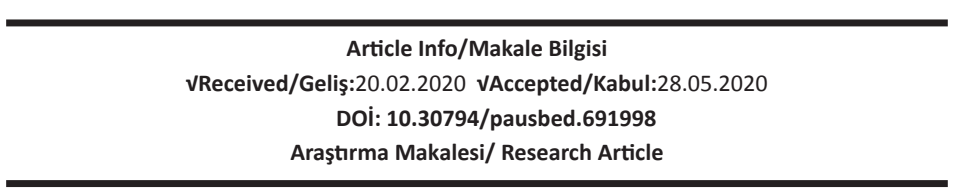

Alkan, M. (2020). "Cem Sultan’ın Türkçe Dîvânı́nda Özgün Benzetme ve Hayaller" Pamukkale Üniversitesi Sosyal Bilimler Enstitüsü Dergisi, sayı 40, Denizli, s. 441-450.

\title{
CEM SULTAN'IN TÜRKÇE DÎVÂNI'NDA ÖZGÜN BENZETME VE HAYALLER*
}

\section{Mustafa ALKAN*}

\section{Özet}

Cem Sultan, gerek tarihî şahsiyet olarak gerekse 15. yüzyıl Türk Edebiyatı'nın başarılı bir şairi olması hasebiyle, hem Türk tarihi hem de Türk edebiyatı araştırmacılarının ilgi odağı olmuştur. Onun Türkçe Dîvân'ı her iki alan için de önemli çıkarım ve sonuçlara ulaşılabilecek bir kaynak eserdir.

Klâsik Türk Şiiri'nde şairler sınırlı teşbih, istiâre ve hayalleri kullanarak şiirler yazmak durumunda kalmışlar; ancak büyük ve usta şairler bu sınırları zorlayarak yepyeni fikir, benzetme ve hayalleri şiir dünyasına katmayı başarmışlardır.

Makale konusunu oluşturan Cem Sultan'ın Türkçe Dîvânı'nda bu türden özgün söyleyişlere, orijinal teşbihlere, hayallere ziyadesiyle rastlamak mümkündür. Bu çalışmada, Cem Sultan'ın Türkçe Dîvânı'ndaki şaire özgü benzetme ve hayaller tespit edilip şairin bu husustaki özgünlüğünü ortaya koymak amaçlanmaktadır.

Bu çalışmada, Cem Sultan'ın Türkçe Dîvânı'ndaki, Klâsik Türk Şiiri'nde çokça rastlanmayan, orijinal benzetme ve hayallerin yer aldığı düşünülen beyitler tespit edilmiş, bu beyitlerdeki özgün benzetme ve hayallerin önceki yüzyıllarda yaşamış ya da şairin çağdaşı olan başka şairler tarafindan kullanılıp kullanılmadığı araştııımıştır.

Anahtar Kelimeler: Cem Sultan, Türkçe Dîvân, Benzetme, Teşbih, Hayal.

\section{ORIGINAL SIMULATION AND DREAMS IN THE TURKISH DIVAN OF CEM SULTAN}

\section{Abstract}

Cem Sultan has been the center of attention for both Turkish history and Turkish literature researchers, both as a historical figure and as a successful poet of 15th century Turkish Literature. His Turkish Divan is a source of inference and conclusions for both areas.

In Classical Turkish Poetry, poets had to write poems using limited simile, metaphor and dreams; however, great and master poets have succeeded in pushing these boundaries and adding new ideas, analogies and dreams to the world of poetry.

It is possible to come across such original sayings, original similes and dreams in the Turkish Language of Cem Sultan, which constitutes the subject of the article. In this study, it is aimed to reveal the poet's unique analogy and dreams in the Turkish Divan of Cem Sultan and to reveal the poet's originality in this regard.

\footnotetext{
*Bu makale, 26-28 Ekim 2017 tarihlerinde Kahramanmaraş Sütçü İmam Üniversitesi'nde düzenlenen 3. Sosyal Bilimler Kongresi'nde sözlü sunumu yapılan tebliğden genişletilerek hazırlanmıştır.

**Öğr. Gör., Afyon Kocatepe Üniversitesi, Eğitim Fakültesi, Türkçe ve Sosyal Bilgiler Eğitimi Bölümü, Türkçe Eğitimi Anabilim Dalı, AFYONKARAHISAR.

e-Posta: alkan@aku.edu.tr (orcid.org/0000-0002-9293-2715)
} 
In this study, the couplets in the Turkish Divan of Cem Sultan, which are not common in the Classical Turkish Poetry, and which are thought to contain the original analogy and dreams, were determined, the original analogy and dreams in these couplets have been explored whether they were used by other poets who lived in previous centuries or were contemporary of the poet.

Key Words: Cem Sultan, Turkish Dîvân, Simulation, Dream.

\section{Giriş}

Cem Sultan'ın kısa hayatı, daha çok tarihçilerin ilgi odağı olsa da; fal kitabı, mesnevisi, Türkçe ve Farsça Dîvân'ları ile o, Türk Edebiyatı'nın önemli şahsiyetlerinden biridir ve bu yönüyle Türk Edebiyatı araştırmacılarının da üzerinde çok çalıştığı bir şairdir. Cem Sultan'ın taht kavgasından dolayı gurbette geçen çile dolu hayatı da ona olan ilginin sebeplerindendir.

Cem Sultan henüz çocuk yaştayken Arapça ve Farsçayı öğrenmiştir. Onun Kastamonu'da şehzade iken, henüz 10 yaşında gazeller yazmaya başladığı rivayet edilmektedir.

Cem Sultan'ın bilinen dört eseri mevcuttur: 1. Türkçe Dîvân 2. Farsça Dîvân 3. Cemşîd ü Hurşîd 4. Fâl-ı Reyhân-ı Cem Sultan.

1. Türkçe Dîvân: Âşık Çelebi'nin verdiği bilgilere göre şair Türkçe Dîvân’ını babası Fâtih Sultan Mehmed adına tertip etmiş, Frengistân'da esaret hayatı yaşadığı zamanda tamamlamış ve Cem şairlerinden Sâdî aracılığıyla Bâyezid'e göndermiştir. Dîvân'ın bilinen on bir nüshası mevcuttur.

2. Farsça Dîvân: Dîvân’ın bilinen dört nüshası vardır. Eser İsmail Hikmet Ertaylan tarafından yayınlanmıştır. İsmail Hikmet Ertaylan’a göre şairin Farsça şiirleri Türkçe şiirlerinden daha üstündür.

3. Cemşîd ü Hurşîd: Selmân-ı Sâvecînnin aynı adlı mesnevîsinin tercümesidir. Eserin bir diğer adı "Âyât-ı Uşşâk"tır. Şâir bu eserini de babası Fâtih Sultan Mehmed adına yazmıştır.

4. Fâl-ı Reyhân-ı Cem Sultan: 48 beyittir. Eserin iki nüshası mevcuttur. Şair, çiçeklerle sevgilinin güzellik unsurlarını esas alarak bir fal tertip etmiştir. ${ }^{1}$

Cem Sultan, Klâsik Türk Edebiyatı şairleri arasında birinci sınıf şairlerden olmasa da başarılı şairlerden biridir. Âşık Çelebi, Lâtîfî ve Gelibolulu Âlî, tezkirelerinde Cem Sultan'ın şiirinden övgüyle bahsetmektedirler. Şair, şiirlerinde duygularını rahatlıkla ifade eden ve hislerini gizlemeyen bir üslûba sahiptir. Onun şiirleri, çileli hayatının ve bu hayatındaki çok az neşeye karşılık yoğun kederinin tercümesidir. Şairdeki duygu yoğunluğu o kadar fazladır ki klâsik şiirde çoğunlukla bir beyitte tamamlanan anlam, onun şiirlerinde birden fazla beyitte ancak tamamlanır. Ondaki bu duygu yoğunluğu ve bunu açıkça dile getirmesi, ona yapaylıktan uzak ve samimi bir söyleyiş kazandırmıştır. ${ }^{2}$

"Üslûbun oluşmasında toplumun ve kültürün etkisi büyüktür. Sanatçının kişisel özellikleri de sanatçının üslûbunun oluşmasında etkili olur. Yaşadığı dönemin insanı olmayan bir sanatçı, kendi üslûbunu oluşturamaz. Sanatçı, yaşadığı dönemde hayata dair üç tercihten birini seçer: Hayatı benimseme, var olana tepki ve içe dönük idealist yaklaşım." (Turgut, 1993: 149) Şairin üslûbu bu etkenler açısından değerlendirilirse o, aldığı eğitim neticesindeki geniş kültürüyle, gerek şehzadeliğinde Anadolu'da yaşadığı güzel yıllar gerekse gurbetteki çileli hayatıyla, yaşadığı dönemi çok iyi idrak etmiş; şiirine hem hayata ve kadere serzenişlerini hem de Allah'a tevekkülünü bir arada yansıtmıştır. Yani hem benimsemeyi hem tepkiyi onun şiirlerinde görmek mümkündür ve onun üslûbunun oluşmasında yaşadıklarının etkisi büyüktür.

Cem Sultan'ın şiir dilinde dönemin şiir anlayışına paralel olarak Arapça ve Farsça kelimelerin Türkçe kelimelere nazaran daha yoğun olduğu fark edilir. Ancak bu durum onun üslubunu olumsuz olarak etkilememiş anlaşılırlığına

1 Cem Sultan’ın eserleri ve edebî kişiliği hakkında ayrıntılı bilgi için bkz: Kut, 1993: 284-286.

2 Ayrıntılı bilgi için bkz. Engin, 2006: 39-40. 
halel getirmemiştir. Çünkü kullandığı Arapça-Farsça kelimeler Klâsik Türk Şiiri kelime hazinesinde sıkça karşılaşılan ve şiir meraklılarının hemen anlayabileceği kelimelerdir. ${ }^{3}$

Âgâh Sırrı Levend'e göre Klâsik Türk şairi, geleneğin kendisine sunduğu edebi malzemeyle hüner ve marifet göstermek için şiir yazmıştır. "Şairler, şiir için "semt-i hüner", "meydân-ı hüner", "mülk-i hüner", "lâf-ı hüner", "hadîka-i hüner" ve "ma'rifet" gibi ibareler kullanırlar. Şair yerine de zaman zaman "erbâb-ı hüner", "ehl-i hüner", "ma'rifet erbâbı", "mi’mâr-ı hüner", "kilk-i hüner”, "hüsrev-i mülk-i hüner", "hüner-ver" gibi kelime ve tamlamaları tercih ederler." (Coşkun, 2011: 59) Klâsik Türk şairleri için şiirden maksat hüner icra etmektir. Bu hüner gösterisi en çok söylenmemiş sözü söyleme gayretinde, derin anlam ve hayalleri ortaya koyma çabasında kendini gösterir.

Şiir meydanının en güzel hünerlerinden biri de hayaldir. Şeyh Gâlib’e göre hayal, şairin "rütbe-i i'câzı"dır. (Kalkışım, 1994: 280) Nedîm, özgün şiirlerinin kaynağı olarak kendi hayal gücünü gösterir ve şairden "taze hayal”in beklendiğini ifade eder. (Gölpınarlı, 1972: 8, Macit, 1997: 276). Necâtî, “hayal”i bir geline, şairi “meşşâta"ya yani gelini süsleyen kişiye, lâfızları da bu gelinin süslerine teşbih eder (Tolasa, 1982: 26). ${ }^{4}$

Malum olduğu üzere, Klâsik Türk Şiiri kuralcı yapısı ve değişmez şiir geleneği, belirli teşbih ve mecaz dünyası ve bu dünyanın dışına pek fazla çıkılamaması ile eleştiri konusu olmuştur. Şairler sınırlı teşbih, istiâre ve hayalleri kullanarak şiirler yazmak durumunda kalmışlar ancak büyük ve usta şairler bu sınırları zorlayarak yepyeni fikir, benzetme ve hayalleri şiire katmayı başarmışlardır. Şiirde esas olan öğelerden birinin de özgünlük olduğunu düşünürsek Klâsik Türk Edebiyatı şairlerinin kendilerine has, ilk kez kendileri tarafından ortaya konan benzetme ve hayalleri o şairlerin kıymetini göstermesi açısından önem taşımaktadır.

El değmemiş ve ilk olarak söylenen söz, mana ve mazmunlara eskiler "bikr-i fikr", "bikr-i mânâ" ya da "bikr-i mazmûn" (Devellioğlu, 2006:103) adlarını vermişlerdir ki Cem Sultan’ın Türkçe Dîvânı'nda bu tarz söyleyişlere, teşbihlere, hayallere ziyâdesiyle rastlamak mümkündür. Bu çalışmada, şairin yazıya konu Dîvân'ında, Klâsik Türk Şiiri'nde çokça rastlanmayan, orijinal benzetme ve hayallerin yer aldığı düşünülen beyitler tespit edilmiş, bu beyitlerdeki özgün benzetme ve hayallerin önceki yüzyıllarda yaşamış ya da şairin çağdaşı olan başka şairler tarafından kullanılıp kullanılmadığı araştırılmıştır. Bu özgünlüğü tespit edebilmek için; Doç. Dr. İskender Pala, Ansiklopedik Divan Şiiri Sözlüğ̈̈; Ahmet Talat Onay, Eski Türk Edebiyatında Mazmunlar; Ahmet Atilla Şentürk, Osmanlı Şiiri Kılavuzu; İsmail Erünsal tarafından yayımlanan Muîdî'nin "Miftâhu't-Teşbih"i, en önemlisi de www. tebdiz.com (Tarih ve Edebiyat Metinleri Bağlamlı Dizin ve İşlevsel Sözlüğü) taranmış, araştırma neticesinde benzetme ve hayaldeki özgünlüğü tespit edilen beyitler incelenmiştir. Yazıda, beyitlerdeki teşbih ve hayallerin özgünlüğü izah edilirken beyitlerin dil içi çevirileri; yapılan teşbih ile kurulan hayali anlamak için açılamaları da yapılmıştır. Seçilen beyitler Dîvân'daki sırasıyla verilmemiş, teşbih ve hayal açısından en özgün olduğu düşünülen örneklerden başlanarak bir sıralama yapılıp açıklanmış, beytin yanına, parantez içinde, kaynakçada belirtilen Ersoylu 2013'teki şiir ve beyit numarası ile sayfa numarası da yazılmıştır.

\section{CEM SULTAN’IN TÜRKÇE DÎVÂNI'NDA ÖZGÜN BENZETME VE HAYALLER}

1. Ka`be yüzüñe Mescid-i Akṣāā disem n'ola

Oldı nişān yüzüñdeki zülfüñ Kamāme'si (329/4; s. 224)

[Kâbe yüzüne Mescid-i Aksâ desem ne olur? Yüzündeki saçların Kamâme'si (buna) işaret oldu.]

Özgün benzetme: Sevgilinin saçlarının Kamâme Kilisesi'ne benzetilmesi.

Şair sevgilinin yüzünü ilk olarak Kâbe'ye benzetmektedir. Nitekim âşığın sürekli döndüğü kıblesi sevgilinin

3 Ayrıntılı bilgi için bkz. age: 41-42.

4 Bkz: Coşkun, 2011: 66.

5 Halil Ersoylu tamlamayı “makșad-ı akșāa” olarak okumuş ve değerlendirmiştir ki bizim de teyit için baktğıımız Cem Sultan'ın Türkçe Dîvânı'nın Milli Kütüphane 06 Mil Yz A 6890 numaralı yazmasının 84b vară̆ı ile yine dîvânın Milli Kütüphane 06 Mil Yz A 1874 numaralı yazmasının 68b varağında tamlama "makșad-1 akșā" olarak kayıtlıdır. Tamlama bu şekilde okunduğunda "en uzak, son, en önemli hedef" anlamına gelmektedir ki mısra bu şekilde düşünüldüğünde sevgilinin yüzü ulaşılmak istenen en son hedef olmaktadır. Mısra bu şekilde düşünülüp anlamlandırılabilir. Ancak bu okuma ve anlamlandırmayı ikinci mısrada geçen Kudüs'teki Kamâme Kilisesi ile ilişkilendirmek biraz güçleşmektedir. Dîvân’ın Milli Kütüphane'de 06 Mil Yz FB 250 numarada kayıtlı yazma nüshasının 97a varağında ise tamlama "Mescid-i Akṣā" olarak kayıtlıdır ki tamlama bu şekilde okunduğunda ikinci mısradaki Kamâme Kilise'si ile mânâ irtibatı kurmak daha kolaylaşmaktadır. Bu nedenle tamlamanın "Mescid-i Akșāa” olarak okunması gerektiğini düşünüyoruz. 
yüzüdür. Bununla birlikte yüzde bulunan mihrap şeklindeki kaşlar, yüzü kıble yani Kâbe yapan unsurlardır. Ancak şair, sevgilinin yüzüne Mescid-i Aksâ demenin de uygun olacağını düşünmektedir; çünkü Mescid-i Aksâ da Müslümanların ilk kıblesidir. Fakat şaire sevgilinin yüzünü Mescid-i Aksâ olarak düşündürten sebep bundan ziyade, sevgilinin yanağının yanlarından sarkan saçlarıdır. Bu saçlar Kamâme Kilisesi'ne benzetmektedir.

Kamâme Kilisesi, Îsâ Peygamber'in kabrinin bulunduğu yer olduğuna inanılan Golgotha Tepesine, 326-335 yılları arasında Imparator Konstantinos'un annesi Helena tarafından inşa edilmiştir. Hazret-i Îsâ'nın burada yeniden dirildiğine inandıklarından bu kiliseye Yunanlılar Anastasis (yeniden dirilme) ya da Resurrection (yeniden dirilme) demişlerdir. Araplar da bu kiliseyi "yeniden dirilme" anlamındaki bu kelimelerin Arapça'daki karşılığı olan "kıyâmet" kelimesi ile adlandıııp kiliseye "Kıyâmet Kilisesi" adını vermişlerdir. Yine bu kiliseye Hz. Îsâ’nın kabri manasında "Merkad-i Îsâ Kilisesi" de denmektedir. Kilisenin en yaygın ismi ise Kamâme Kilisesi'dir. "Kamâme" kelimesinin Arapça'daki anlamı "süprüntü, çöplük"tür. Eski bir Hıristiyan anlatısına göre, Îsâ Peygamber'in çarmıha gerilmesinden sonra, Yahudilerin gömdüğü çarmıh, Bizans İmparatoriçesi Helena tarafından bulunana kadar enkaz ve çöplüğün altında kalmıştır. Çöplüğün altından çıkan haçın üstüne inşa edildiği için kilise "Kanisât-ı Kumâma" olarak anılmışır. Bu kiliseye daha sonra "Kamâme" denmiştir. Evliya Çelebi de kitabında bu kiliseden "Kamâme" adıyla bahseder. ${ }^{6}$

Saçlar siyahlığı itibarıyla kâfir olduğu için bu kâfir saçları kâfirlerin kutsal kilisesine benzetmek akla yatkın bir benzetmedir. Saçlar Kamâme olunca saçın yanı başındaki yüz de kıble ve dahi ibadethane olan Mescid-i Aksâ olacaktır.

Şairin saçları Kamâme'ye benzetmesindeki bir diğer sebep de Kamâme Kilisesi'nin bulunduğu yerin Hz. Îsâ sanılarak çarmıha gerilen ve idam edilen Yehuda'nın çarmıha gerilip öldürüldüğü yer olmasıdır. Nitekim Türk edebiyatında saç, âşıkların gönüllerinin asılı olduğu bir darağacıdır. Saçlar darağacı olunca Yehuda'nın idam edildiği yer olan Kamâme'ye benzetilmesi de doğaldır. Bu benzetme Cem Sultan'a özgü bir benzetmedir. Girişte bahsedilen kaynaklarda yüzün birçok unsura benzetildiği görülse de Mescid-i Aksâ'ya benzetildiğine rastlanmamıştır. Bu benzetme de özgün bir benzetme olarak değerlendirilebilir.

2. Zāhid ki țacn iderdi mey-i ' 1 ş̧̧̦a dün ü gün

Mey-hāne içre başda sebūdur cimāmesi (329/2; s.223)

[Zâhid aşk şarabını gece gündüz kınardı. (Şimdi) meyhane içinde (zâhidin) baş(ın)daki sarığı şarap testisidir.]

Özgün benzetme: Şarap testisinin zâhidin sarığı olarak düşünülmesi/şarap testisinin sarığa benzetilmesi.

Zâhid, Klâsik Türk Şiiri'nde âşık ya da sûfînin zıddı olarak değerlendirilebilecek insan tipidir. Zâhid, dünya zevkiyle meşgul olmamakla birlikte, dini dıştan görüp ondaki özü kavrayamayan ve Cennet arzusu ile Cehennem korkusundan öteye geçemeyen kişidir. Sûfî ya da âşı̆̆ı yaşantısından dolayı kınar ve insanları Cehennemle korkutur.7 Beyitte zâhidin aşk şarabını kınadığı görülmektedir. Hem de bunu "dün ü gün" yani gece gündüz, sürekli yapmaktadır. "Dün ü gün" aynı zamanda "geçmiş ve hâlen" olarak da anlaşılabilir. Bu ifade zâhidin kınamayı âdet haline getirdiğini gösterir. Tâ ki bu durum onun aşk ile aşk şarabıyla tanışmasına kadar sürer. Zâhid aşk ile meyhanede tanışmışır. Daha önce meyhane ve şaraptan haramlığı sebebiyle uzak duran zâhid ondaki anlamı fark edince kendini meyhane içinde, şarap testisini de baş üstünde bulmuştur. Meyhane, tasavvûfî düşüncede ilâhî aşk ve marifet sırrının öğrenildiği, yaşandığı, keşfedildiği tekkedir. ${ }^{8}$ Şarap “ilâhî aşk"ın ve "marifet"in remzidir. ${ }^{9}$ ilâhî aşkla tanışana kadar, marifet sırrııın en cüzîsinin dahi farkına varana kadar zâhid, başkalarını kınamakla meşguldür. Bundan dolayı da kendini bilemeyen, kendi eksiğini göremeyen zâhid, aşkı tanıdıktan sonra kınamayı terk edip âşık olmuştur.

Aşkın, aşk şarabının en mühim tarafı kişiyi "öncesi” ve "sonrası" olarak iki farklı insan yapmasıdır. Aşk, kişinin hayatında bir değişiklik yapabiliyorsa aşktır. Nitekim aşktan önce "zâhid" olan aşktan sonra "âşık" ya da "sûfi" olmuştur.

6 Ayrıntılı bilgi için bkz: Akyol, 2019.

7 Zâhid için bkz: Pala, 2002: 501.

8 Meyhane için bkz: Cebecioğlu, 2004: 435

9 Şarap (mey) için bkz: Pala, 2002: 326, 62. 
Zâhid, dini şekil olarak gören ve yaşayan kişidir. O nedenle de zâhid kişi çoğunlukla sakal, sarık, hırka gibi şeklî unsurlara sarılır. Ancak sûfînin ya da âşığın meşguliyeti şekille değil özledir. ${ }^{10}$ Zâhid, şekilciliği de terk ederek öncesinde taktığı sarığını çıkarmış, onun yerine "imâme" (sarık) olarak şarap testisini koymuştur. Yani zâhidin yerini âşık, sarığın yerini de sebû almıştır. Türkçe'de kıymet verilen kişi ve varlıklar ifade edilirken "baş üstüne / baş üstünde" tabiri kullanılır. Burada zâhid, aşk şarabı testisini kıymetinden dolayı âdeta başında taşımaktadır. Nitekim hakiki manada testinin içindekini içebilmek için onu elle baş üstüne çıkarmak gerekir. Aşk şarabını da içebilmek için onu baş üstünde taşımalıdır ki, o aşk kişiye tesir etsin.

Şair özgün bir benzetme olarak şarap testisini (sebû) başa sarılan sarığa (imâme) benzetmektedir. Bunu yaparken testinin şekil olarak tespihlerdeki imameye benzemesinden ve "imâme" kelimesinin aynı zamanda "sarık" manasına gelmesinden faydalanmıştır. Yine şarap testisinin şarap içmek için başa kadar taşınmasını ona kıymet verildiğini ortaya koymak, sarığın sürekli başta taşınan bir nesne olması itibarıyla da aşkta devamlılığı ifade etmek istemiştir.

3. 'Anberīn zülfüñ ne hoş şīāze-i müşgīn olur

Şol kitāb-1 ḥüsne kim alnuñdur anuñ mıḳlebi (320/3; s.219)

[Şu güzellik kitabına -ki onun mıklebi alnındır- amber kokulu saçın ne hoş misk kokulu şîrâze olur.]

Özgün benzetme: Sevgilinin alnının kitap mıklebine benzetilmesi.

Sevgilinin güzelliğini anlatmak için en çok yüz üzerinde durulur. Çünkü saç, kaş, ben, göz, kirpik, hat gibi teşbih, istiâre ve mecaza en çok konu olan güzellik unsurları yüzde toplanmıştır. Yüz ve sevgilinin güzelliği çeşitlisebeplerden ötürü yaygın bir şekilde kitaba teşbih edilmiştir. ${ }^{11}$ Şair sevgilinin amber kokulu saçını şîâazeye benzetmektedir. Bunda saçların şekil itibarıyla iplik iplik oluşundan hareket edilmiştir. Nitekim şîâazeler ibrişimden örülüp kitap sayfalarının dağıımasını engeller. Yine şîâzeler kitabın alt ve üst kenarlarına örülür. Sevgilinin yüzü kitaba teşbih edildiğinde saçlar yüzün iki yanında yer alması hasebiyle de şîrâzeye benzemektedir. Beyitte üzerinde durulması gereken özgün teşbih, alnın kitap mıklebine benzetilmesidir. Mıklep, kitabın sol tarafındaki dış kapağının devamı şeklinde olan çıkıntıdır. Kitapta okunmaya devam edilecek sayfanın olduğu yere, sayfaların arasına sokulur. ${ }^{12}$ Şair, sevgilinin alnını mıklep olarak düşünmektedir. Sevgilinin güzelliği ya da yüzü kitap olduğunda alın, başta ve yüzün devamı olarak yer aldığından, mıklep olacaktır. Sevgilinin güzelliğinin/yüzünün kitaba, hattının yazıya, şaçlarının şîrâzeye benzetilmesi alışılagelmiş teşbihler olmasına rağmen; girişte belirtilen kaynaklarda alnın mıklebe teşbihine rastlanamamıştır. Bu nedenle şairin alınla ilgili bu teşbihi özgün bir benzetmedir.

4. Lebüñ hālini zülfüñ halḳası çekmiş kenārına

Ṣanasın ṭış-iken ‘īsā yatur Meryem ḳucag̉ında (286/2; s.201)

[(Ey sevgili,) saçının halkası dudağının benini kenarına (yanına) çekmiş. (Bu hâli) çocuk iken Meryem'in kucağında yatan Îsâ sanırsın.]

Özgün benzetme: Sevgilinin dudağındaki benin Hz. Îsâ'ya teşbihi.

Hazret-i Meryem'in kucağındaki bebeklik çağındaki Hz. Îsâ görüntüsü hem Batı resim sanatında hem de Klâsik Türk Şiiri'nde çok yaygın olarak kullanılan bir motiftir. Yine sevgilinin saçının siyahlığından dolayı Hz. Meryem'e teşbihi alışılmış bir teşbihtir. ${ }^{13}$ Ancak beyitte Cem Sultan, gerek kucağında Îsâ bulunan Meryem hayaline gerekse saç-Hz. Meryem teşbihine, farklı bir benzetmeyle katkıda bulunmaktadır ki, o da sevgilinin beninin çocukluk

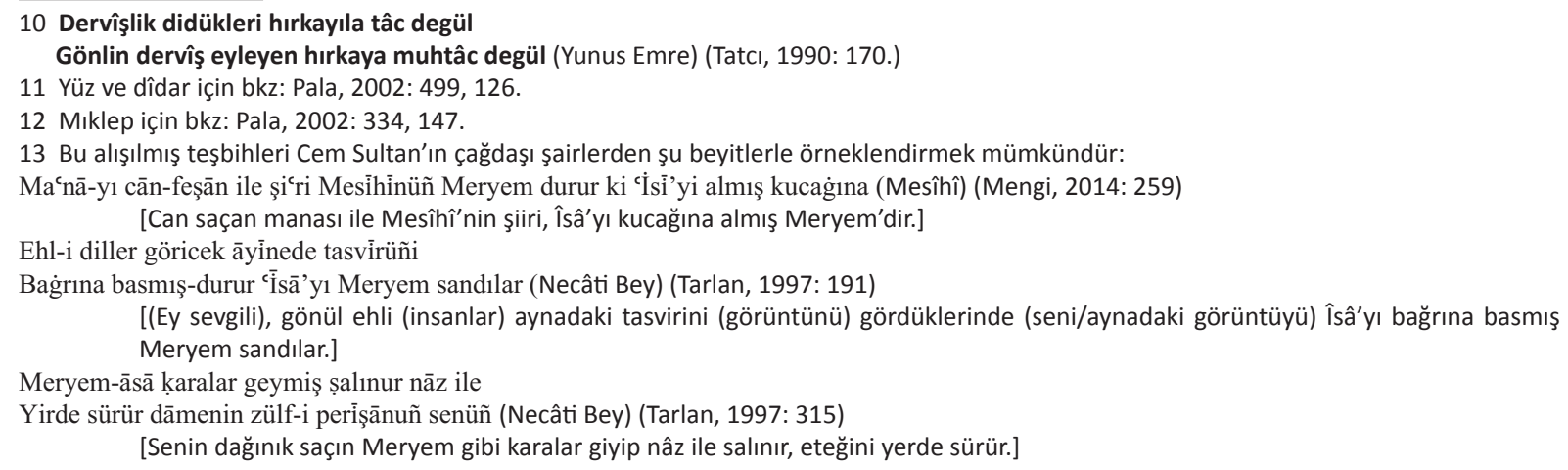


çağında ve Hz. Meryem'in kucağındaki Hazret-i Îsâ'ya benzetilmesidir. Sevgilinin yanaklarından sarkan zülfü $\mathrm{Hz}$. Meryem'e teşbih edildiğinde dudağın kenarında nokta halindeki ve saçla yan yana gelen ben de, çocukluk çağında ve Meryem'in kucağında bulunan Îsâ olmaktadır. Bu orijinal teşbihin yapılmasında siyah saçla benin yan yana gelmesi ve nokta hâlindeki benin küçük bir çocuğu andırması etkili olmaktadır.

5. Lāceverdì hatțuñuñ ${ }^{14}$ nakṣsı vü çīn-i zülfüñ

Șırça göñlüm evine eyledi kāşs̄nalığı (331/3; s.224)

[Lacivert hattının nakşı ve büklümlü saçın, gönlümün sırçadan evini yuva etti.]

Özgün hayal: Hattın "lâciverd" olarak düşünülmesi

Beyitte âşığın gönlü, sevgilinin lacivert ayva tüyü ve büklümlü saçı tarafından yuva yapılmıştır. Âşık hiçbir zaman sevgilinin yâdını gönlünden çıkarmaz. O nedenle gönülde hep sevgili olunca âşı̆ın gönlü saç ve hattın yuvası olmaktadır. Ayrıca şairin gönlü, sevgilinin bir çengel olan saçının ucunda asılı olunca gönülde her zaman saç, saçın ucunda hep gönül vardır. O nedenle saç sanki gönlü evi yapmıştır. Şair gönlünü "sırça" olarak nitelemiştir. Bunda gönlünün, arzularına erişemediğinden dolayı, daima kırılmış vaziyette oluşunun etkisi vardır. O hâlde saç ve hat, camdan bir evi kendilerine mekân edinmişlerdir; o ev hep kırık dökük ve viranedir.

Hattın siyah ya da yeşil olması sıradandır ancak burada "çîn-i zülf” (büklüm büklüm saç) tamlamasındaki "çini" kelimesi ile "nakş" kelimesinin yaptığı çini sanatı çağrışımından dolayı hatt, lacivert olarak hayal edilmiştir. Hattın lâcivert olması klâsik Türk şiirinde sıra dışı bir hayaldir ve Cem Sultan'a aittir.

6. Zülfnde iken sihrüñe aḥsente senüñ kim

Rām eyledüñ ejderleri fermānuña şāne (293/4; s.205)

[(Ey) tarak, (sevgilinin) saçında iken senin sihrine ahsente ${ }^{15}$ ki ejderleri fermanına itaat ettirdin.]

Özgün benzetme: İstiâre yoluyla, tarağın ferman sahibi bir padişaha benzetilmesi.

Şair, klâsik bir benzetme olarak sevgilinin saçlarını ejderha olarak düşünmektedir. Bununla saçların son derece acımasız, bir yönüyle de itaat etmez bir varlık olduğu ifade edilmektedir. Ancak saç ejderini kendine itaat ettiren sadece taraktır; tarak, sevgilinin saçlarındayken, bir büyücü gibi onu kendine bağlayıp ondaki kıvrımları tek tek açarak kendi emrine itaat ettirmektedir. Ancak bundan daha ötede göze çarpan benzetme ise tarağın ferman veren ve ejderleri fermanıyla itaat altına alan bir padişah olmasıdır. Tarak, saçlara şekil vermesinden dolayı, isteğine (fermanına) boyun eğdiren bir padişah olarak düşünülmektedir.

7. Olmasa hālüñ âf-tâb-perest

Ḳılmaz-1dı güneş yüzüñe sücūd (36/3; s.62)

[(Ey sevgili), benin Güneş'e tapan olmasaydı güneş yüzüne secde kılmazdı.]

Özgün hayal: Sevgilinin beninin Güneş'e tapması ve sevgilinin güneş gibi olan yüzüne secde etmesi.

Klâsik Türk Şiiri'nde, sevgilinin güzellik unsurlarının ve diğer varlıkların, en başta put olan sevgilinin kendisine, sonra sevgilinin yüzüne, boyuna, kaşına, saçına secde ettiği birçok beyit görülür. ${ }^{16}$ Cem Sultan'ın beytinde de

14 Kelime Ersoylu, 2013: 224'te “ḩațuñuñ” şeklinde kayıtlıdır. Ancak kelimenin "ḩaț̣uñuñ” şeklinde okunması gerekir. Kelime için bkz. Redhouse, 1921: 852.

15 Ahsente: “En iyisin, en güzelsin, bravo!” manasında takdir, alkış ifadesi.

(Bkz: http://www.lugatim.com/s/ahsent) (06.05.2020)

$16 \mathrm{Bu}$ beyitlere birkaç örnek:

Menden yüzüñ yaşurma kim secde-gâhum oldur

Seyr iderem bu çarḩı hurşīi ü māhum oldur (Nesîmî) (Ayan, 2014: 238)

[Benden yüzün gizleme ki secde yerim odur. Bu feleği seyrederim güneş ve ayım odur.]

Zülfeynün arasında görüp yüzüni sandum

Bir sîm büte secde kılur iki siyeh-pûş (Hamdî) (Özyıldırım, 1999, Gazel 71)

[(Ey sevgili), iki zülfünün arasında yüzünü görüp iki siyah örtü bir gümüş puta secde eder sandım.]

'Ar'ar-1 bāg̀-1 cinān secde itmeseydi ḳaddüñe

Ser-ferāz olup Cennetde bulmaz idi irtifāc (Sarıca Kemâl) (Walsh, 1979, Gazel 18)

[Cennet bahçesinin arar (ağacı) (senin) boyuna secde etmeseydi Cennet'te muteber olup yükselmezdi.]

Kaşlaruñ miḥrābına secde ider ehl-i șalāt

Küfr-i zülfüñe perestār iy șanem ehl-i șalīb (Adlî) (Bayram, 2018: 48)

[Ey put (gibi olan sevgili) namaz ehli mihrap olan kaşlarına secde eder, haç ehli (ise) kâfir saçına tapıcıdır.] 
sevgilinin yüzü parlaklığı nedeniyle güneş olarak düşünülmektedir. Güneş çok eski zamanlarda insanlar tarafından Tanrı yerine konulup tapılan bir varlıktı. ${ }^{17}$ Beyitte şair 15 . yüzyıl ve öncesinde karşılaşmadığımız bir ayrıntı olarak sevgilinin benini "af-tâb-perest" (Güneş'e tapan) olarak nitelemektedir. Sevgilinin beninin Güneş'e tapıcı olarak düşünülmesine sebep siyahlığından dolayı kâfir olarak nitelenmesidir.

8. Ko kemer olsun ḳolum bilüñe iy cān-1 cihān

Ḥoş yaraşur olıcak sỉminn miyāna zer kemer (89/5; s.91)

[Ey cihânın cânı (sevgili), bırak kolum beline kemer olsun. Gümüş bele altın kemer hoş yakışır.]

Özgün benzetme: Âşığın kendi kolunu altın kemere benzetmesi.

Şair, sevgiliye sarılma isteğini "ko kemer olsun kolum bilüne" ifadesiyle dile getirirken bu isteğe bir gerekçe olarak, sevgilinin belini gümüşe kendi kolunu da altına benzetmekte ve altınla gümüşün birbirine çok yakışacağını ifade etmektedir. Nitekim "gümüş" kelimesinin hemen yanında "altın" kelimesi "zer ü sîm" ifadesiyle çokça kullanııır. O hâlde şair, sevgilinin belinin gümüş olmasından yola çıkarak gümüşün yanına lâyık olan altının da kendi kolu olduğunu bildirmektedir. Klâsik Türk Şiiri'nde altınla ilgili çok benzetmeye rastlansa da şairin kendi kolunu altına benzetmesi özgün bir benzetme olarak karşımıza çıkmaktadır.

9. Hayme ḳursa her ne gül-zār içre Ṭūbā ḳāmetüñ

Her ṭnābınuñ ola kim mîhi bir serv-i sehì (330/2; s.224)

[Tûbâ (gibi uzun) boyun hangi gül bahçesi içine çadır kursa çadırın her ipinin çivisi dümdüz bir servi olur.]

Özgün benzetme: Bahçedeki dümdüz servinin sevgilinin Tûbâ boyunun kurduğu çadırın ipinin mıhı olması, servinin çadır mıhına benzetilmesi.

Sevgilinin boyu yaygın bir teşbih olarak Tûbâ ve servi ağacına benzetilir. Bu beyitte, Tûbâ ağacının bütün Cennet'i gölgelemesi ilgisinden dolayı, boy çadır ile ilişkilendirilmekte, sevgilinin boyu çadır kurmuş olarak düşünülmektedir. Sevgilinin boyunun çadır olarak düşünülmesi orijinal bir hayal olarak değerlendirilebilir. Bunda, Tûbâ ağacının şekli, bu hayale giden yolu oluşturmaktadır. Burada değinilmek istenen esas teşbih ise servi ağacının sevgilinin kurduğu çadııın çivisine benzetilmesidir. Bu teşbihte servinin düz olması ile çivi arasında ilişki kurulmuştur ve bu teşbih şairin özgün benzetmelerindendir.

10. Her gice ag̉layup yaşı seyyāresin döker

Beñzer gözine girdi semānuñ duhān-1 şem (161/8; s.133)

[Gökyüzü, gözüne mumun dumanı girmiş gibi, her gece ağlayıp (göz) yaşı seyyâresini döker.]

Özgün hayal: Gökyüzünden yağan yağmurun sebebi olarak gökyüzünün gözüne mumun dumanının kaçmasının gösterilmesi.

Hüsn-i ta'lîl sanatı Klâsik Türk Şiiri'nde hem şairin hayal gücünü ortaya koyan hem de anlatıma çeşni katan en önemli sanatlardan biridir. Bu beyitte şairin, hüsn-i ta'lîl ile, geceleyin yağmurun yağması gibi bir tabiat hâdisesini "göğün gözüne mumun dumanının gitmesi" olarak sebeplendirdiği görülmektedir. Mum geceleyin yandığından göğün gözüne mumun dumanı kaçınca yağmur da geceleyin yağmakta, yani gök geceleyin ağlamaktadır.

11. Çün meyi laclüne ḳ̂lur teşbīh

Niçün olmaz șurāḥi ḳanı mubāḥ (28/6; s.59)

[(Ey sevgili) şarabı dudağına benzettiği için neden sürahinin kanı mubah olmaz?]

Özgün hayal: Sürahinin yaptı̆̆ı yanlış teşbihten dolayı ölümü hak etmesi, kanının mubah olmasının gerektiği.

Sürahinin kanı olarak nitelenen şarabın haram ya da mubah oluşu Klâsik Türk Şiiri'nde çokça bahsi edilen bir konudur. Renk itibarıyla kırmızı olması la'l olan dudağın rengiyle irtibatlandırıır. ${ }^{18}$ Beyitte sürahi, büyük bir hata yapmış ve şarabı sevgilinin dudağına benzetmiştir. Ancak şair, böyle bir teşbihi uygun görmemekte ve bu nedenle

17 Bu hususta bkz: Karaman vd., 2016 C.4: 712-713.

18 Şarap-dudak ilgisi için bkz: Pala, 2002: 62. 
sürahinin kanının mubah olması gerektiğini, yani sürahinin öldürülmesi lâzım geldiğini ifade etmektedir. İslâm'da şarap haramdır, mubah değildir. Şair ise, sürahinin yaptığı hatalı teşbih sebebiyle onun kanı olan şarabın mubah olması gerektiğini sanatlı bir söyleyişle ifade etmektedir.

12. Leblerüñ yādına ölen kabrini

Kim ḳazarsa la`l-i gevher-bār alur (96/3; s.95)

[(Ey sevgili,) dudaklarının hatııına ölenin kabrini kim kazarsa saçılmış lâl cevheri alır.]

Özgün hayal: Sevgilinin dudakları uğruna ölen kişinin kabrinde mücevherin olması, o kabri kazanın mücevhere erişmesi.

Sevgilinin dudaklarııın rengi ve kıymetinden dolayı lâl olması hasebiyle, sürekli sevgilinin dudağını hayal eden ve onun hatırına ölen kişinin dünyada kavuşamadığı "lâl”e kabirde kavuşacağı vurgulanmaktadır. Kişinin nasıl yaşarsa öyle ölüp öyle diriltileceği anlamındaki merfû́ ${ }^{19}$ hadis gereğince, ${ }^{20}$ lâl için ölenin de kabrinde lâller içinde olacağı düşünülebilir. Şair, bu özgün hayali o kişinin kabrini açanın "lâl"e erişeceği şeklinde ifade etmektedir. Nitekim lâl gibi kıymetli madenler toprak altındadır ve toprak kazılınca ona erişilir. O halde lâlin bulunduğu toprak da, lâl uğruna ölenlerin mezarıdır.

13. Ne șafādur baña sen būseñi virmezlenesin

Ben alam leblerüñi aġzuma yil-vārī öpem (226/2; s.169)

[Senin bûseni vermezlenmen (vermek istememen) bana gönül şenliğidir. Ben dudaklarını ağzıma alıp yel gibi öpeyim.]

Özgün hayal: Âşığın, sevgilinin dudağını yel, rüzgâr gibi öpmesi. (Sevgilinin buna engel olması mümkün değil.)

Şair sevgilinin dudaklarını öptürmek istememesini bir keder olarak görmeyip tam tersine bunu daha hoş bir durum olarak değerlendirmekte, kendisinin yel gibi, sevgilinin dudaklarını öpeceğini ifade etmektedir. Sevgilinin, dudaklarını öptürmek istemese de, yele engel olması mümkün değildir. Ayrıca "yil-vârî" kelimesi "yalvar-mak" eylemini akla getirmektedir, sevgilinin bûsesini vermezlenmesi üzerine, âşığın yalvarmak yoluyla onu öpmesi düşünülmektedir. Sevgilinin nazına karşı dudaklarını çokça yalvarmak yoluyla öpmek de âşık için ayrı bir safa sebebi olacaktır. ${ }^{21}$

\section{Sonuç}

Yukarıda ele alınan beyitlerdeki özgün benzetmeleri sıralamak gerekirse saç, Kamâme Kilisesi'ne; yüz, Mescid-i Aksâ'ya; şarap testisi, sarığa; alın, mıklebe; ben, Hazret-i Îsâ'ya; tarak, padişaha; âşs̆ıın kolu, altın kemere; servi ağacı, sevgilinin Tûbâ boyunun kurduğu çadır ipinin mıhına (çadır mııına) benzetilmektedir. Şairin özgün hayalleri ise sevgilinin hattının (ayva tüyü) lacivert olması, beninin Güneş'e tapması, yağmurun geceleyin yağma sebebi olarak göğün gözüne mumun dumanının kaçmasının gösterilmesi, sürahinin yanlış bir teşbih yapıp sevgilinin dudağını şaraba benzetmesinden dolayı kanının mubah olması (öldürülmesi ve şarap içmenin mubah olması), Sevgilinin dudakları uğrunda ölenin kabrinde mücevher olması, o kabri kazanın mücevhere erişmesi, âşığın sevgilinin dudağııı yel gibi öpmesidir. Bu benzetme ve hayaller dikkate alındığında Cem Sultan'ın şiire, çağdaşlarından ve kendisinden önceki şairlerden farklı birçok özgün benzetme ve hayali kattı̆̆ı görülmektedir. Bundan dolayı onun Klâsik Türk Şiiri'ndeki kıymetli yeri, bir kere daha takdir edilecektir. Yine Cem Sultan'ın ortaya koyduğu özgün söyleyişlerle kendisinden sonraki şairlerin ve Klâsik Türk Şiiri'nin hayal dünyasını genişlettiği söylenebilir.

Böylesi çalışmalar, hem Klâsik Türk Edebiyatı geleneğine mensup diğer şairlerde hem de Klâsik Türk Edebiyatı ile Fars Edebiyatı ve Arap Edebiyatı arasında yapıımalıdır. Böylece, hem Klâsik Türk Edebiyatı'nın kendi içindeki hem de Müşterek İslâm Edebiyatları arasındaki özgünlüğüne dair ipuçlarına ulaşılabilir.

19 Merfû: Hazreti Peygamber'e nispet edilen söz ve haber anlamındaki hadîs ilmi terimi. (Bkz. Aydınlı, 2014: 180)

20 "Her bir kul, hangi hâl üzere vefat ettiyse, o hâl üzere diriltilir." Avcı, 2016'dan naklen Müslim, 1970: VIII/401-02.

21 "Yil-vârî" kelimesi ile "yalvar-mak" kelimesi arasında kökenbilim açısından bir irtibat olmasa da iki kelimenin sesleri itibarıyla insan zihninde meydana getirdikleri çağrışım dikkate değerdir. 


\section{Pamukkale Üniversitesi Sosyal Bilimler Enstitüsü Dergisi, Sayı 40, Temmuz 2020 M.Alkan}

\section{Kaynakça}

AYDINLI, A. (2014). Merfû, TDV İslam Ansiklopedisi, (C.29, s.180-181), TDV Yayınları, Ankara.

AKYOL, Y. E. (2019). 19. Yüzyılın Ikinci Yarısında Kudüs Kamame Kilisesi Üzerine Osmanlı Politikaları, Yüksek Lisans Tezi, Pamukkale Üniversitesi, Denizli.

AKDOĞAN, Y. Ahmedî Dîvân, Kültür ve Turizm Bakanlı̆̆ı Yayınları, e kitap, (https://ekitap.ktb.gov.tr/TR-78357/ ahmedi-divani.html) (05.12.2019).

AYAN, H. (2014). Nesîmî Hayatı, Edebî Kişiliği, Eserleri ve Türkçe Divanının Tenkitli Metni, Türk Dil Kurumu Yayınları, Ankara.

AVCI, ì. (2016). 16. Asır Şairlerinden Lutfî́nin Manzum Kırk Hadisi, Divan Edebiyatı Araştırmaları Dergisi, S. 16, s. $1-32$.

BATiSLAM, H. D. (2011). Divan Şairinin Benzetme Dünyasında Mısır ve Nil, Turkish Studies-nternational Periodical ForTheLanguages, Literature and History of Turkish or Turkic Volume 6/1 Winter 2011, p. 203-210.

BAYRAM, Y. (2018). Adlî Dîvânı (Dîvân-ı SultânBâyezîd-i Sânî), Kültür ve Turizm Bakanlığı Yayınları, e kitap. (https://ekitap.ktb.gov.tr/TR-215522/adli-divani.html) (05.12.2019).

BEŞiROV, K. (2001). Gurbetnâme-i Sultan Cem (Giriş-Inceleme-Metin-Sözlük), Yüksek Lisans Tezi, İstanbul Üniversitesi, İstanbul.

CEBECiOĞLU, E. (2004). Tasavvuf Terimleri ve Deyimleri Sözlüğü, Ağaç Kitabevi Yayınları, İstanbul.

CEM SULTAN. Dîvân, Milli Kütüphane Yazmalar Koleksiyonu, 06 Mil Yz FB 250, 97a varak, Milli Kütüphane.

CEM SULTAN. Dîvân, Milli Kütüphane Yazmalar Koleksiyonu, 06 Mil Yz A 6890, 84b varak, Milli Kütüphane.

CEM SULTAN. Dîvân, Milli Kütüphane Yazmalar Koleksiyonu, 06 Mil Yz A 1874, 68b varak, Milli Kütüphane.

ÇAKMAK, A. S. (2000). Sultan Cem Divanı́nın Psikolojik Tahlili, Yüksek Lisans Tezi, Fırat Üniversitesi, Elazı̆̆.

ÇINAR, B. (2007). Geleneğe Direnen Bir Şair ve Şiiri: Cem Sultan'ın Frengistan Kasidesi, Turkish Studies Internatıonal Periodical Forthe Languages Literature and History of Turkish or Turkic Volume 2/4 Fall 2007, p. $274-282$.

DEVELLioĞLU, F. (2001). Osmanlıca Türkçe Ansiklopedik Lugat, Aydın Yayınevi, Ankara.

DOĞAN, M. N. Avnî (Fâtih) Dîvânı, Kültür ve Turizm Bakanlığı Yayınları, e kitap, (https://ekitap.ktb.gov.tr/TR78360/avni-fatih-divani.html) (05.12.2019).

ELIAÇıK, M. (2013). Bazı Belagat Kitaplarında "Teşbîh" Sanatı Hakkında Tanım Ve Tasnifler, Turkish StudiesInternational Periodical For The Languages, Literature and History of Turkish or Turkic Volume 8/8 Summer, Ankara-Turkey, p. 565-581.

ENGiN, S. (2006). Cem Sultan'ın Türkçe Divanı'nın Tahlili, Yüksek Lisans Tezi, Çukurova Üniversitesi, Adana. ERSOYLU, İ. H. (1981). Fal, Falnâme ve Fâl-i Reyhân-ı Cem Sultan, İslam Medeniyeti Dergisi, C. 10, S. 2. s.69-81.

ERSOYLU, İ. H. (2013). Cem Sultan'ın Türkçe Divanı, Türk Dil Kurumu Yayınları, Ankara.

ERTAYLAN, İ. H. (1951). Sultan Cem, MEB Yayınları, İstanbul.

ERÜNSAL, İ. E. (1998). Muidî'nin Miftâhu't-Teşbîh'i, The Journal Of Ottoman Studies 7-8. İstanbul, s. 215-272.

GÖLPINARLI, A. (1972). Nedîm Divanı, İnkilap ve Aka Kitabevleri, Şenoğlu Matbaası, İstanbul.

iNCE, A. (2000). Cem Sultan, Cemşîd ü Hurşîd, TDK Yayınları, Ankara.

KALKIŞıM, M. (1994). Şeyh Gâlib Dîvânı, Akçağ Yayınları, Ankara.

KARAMAN, H., ÇAĞRICI, M., DÖNMEZ, İ.K, GÜMÜŞ, S. (2016). Kur'an Yolu Tefsiri (C.4, s. 712-713), DiB Yayınları, Ankara.

KILIÇ, F. (2018). Âşık Çelebi Meşâiru'ş-Şuarâ, Kültür ve Turizm Bakanlığı Yayınları, Ankara, e kitap: https://ekitap. ktb.gov.tr/Eklenti/59036,asik-celebi-mesairus-suarapdf.pdf?0 (29.04.2020).

KUT, G. (1993). Cem Sultan’ın Edebî Yönü, İslâm Ansiklopedisi, C. 7. TDV Yayınları, İstanbul, s. 284-286.

LEVEND, A. S. (2015). Divan Edebiyatı (Kelimeler ve Remizler, Mazmunlar ve Mefhumlar), Dergâh Yayınları, 2.Baskı, İstanbul.

MACiT, M. (1997). Nedim Divanı, Akçağ Yayınları, Ankara. 
MENGi, M. (1995). Mesîhî Dîvânı, Türk Tarih Kurumu Basımevi, Ankara.

MÜSLiM, E.H. İbnu'I-Huccâc el-Kuşeyrî en-Nişâbûrî (1970), Sahih-i Müslim ve Tercemesi, (C.8) Tercüme: Mehmed Sofuoğlu, İrfan Yayınları, İstanbul.

OKUR, M. (1991). Cem Sultan'ın Yeni Bulunan Fâl-ı Reyhân-ı Sultan Cem Adlı Mesnevisi, Tarih ve Toplum S.16, s.24-27.

OKUR, M. (1992). Cem Sultan: Hayatı ve Şiir Dünyası, Kültür Bakanlığı Yayınları, Ankara.

ONAY, A. T. (1996). Eski Türk Edebiyatında Mazmunlar, MEB Yayınları, İstanbul.

ÖZYILDIRıM, A. E. (1999). Hamdullah Hamdî Dîvânı, Kültür ve Turizm Bakanlığı Yayınları, e kitap, (https://ekitap. ktb.gov.tr/TR-78375/hamdullah-hamdi-divani.html) (05.12.2019).

PALA, İ. (2002). Ansiklopedik Divan Şiiri Sözlüğü, L\&M Yayınları, Ankara.

REDHOUSE, S.J.W. (1921). Turkish And English Lexicon, American Board Mission, İstanbul.

ŞENTÜRK, A. A. (2017). Osmanlı Şiiri Kılavuzu 1-2, OSEDAM (Osmanlı Edebiyatı Araştırmaları Merkezi), İstanbul.

TARLAN, A. N. (1997). Necati Beg Divanı, Milli Eğitim Bakanlığı Yayınları, İstanbul.

TATCI, M. (1990). Yunus Emre Divânı II Tenkitli Metin, Kültür Bakanlığı Yayınları, Ankara. www.tebdiz.com (Tarih ve Edebiyat Metinleri Bağlamlı Dizin ve İşlevsel Sözlüğü)

TOLASA, H. (1982). Divan Şairlerinin Kendi Şiirleri Üzerine Düşünce ve Değerlendirmeleri, Türk Dili ve Edebiyatı Araştırmaları Dergisi 1: 15-46.

TURGUT, i. (1993). Sanat Felsefesi, Üniversite Kitabevi, İzmir.

YEŞiLÇiÇEK, V. (2001). Edebiyat Teorisi Temel Kitaplarında Teşbih Sanatı, Afyon Kocatepe Üniversitesi Sosyal Bilimler Dergisi, C.2, S.2, s.221-235.

YiĞiterol, Ö, F. (2018). Falnâme-i Cem Sultân, B. Kemikli \& O. Kocatürk (Editör), Cem Sultan ve Dönemi, s.197. Bursa Osmangazi Belediyesi Yayınları, Bursa.

\section{Beyan ve Açıklamalar (Disclosure Statements)}

1. Bu çalışmanın yazarları, araştırma ve yayın etiği ilkelerine uyduklarını kabul etmektedirler (The authors of this article confirm that their work complies with the principles of research and publication ethics).

2. Yazarlar tarafından herhangi bir çıkar çatışması beyan edilmemiştir (No potential conflict of interest was reported by the authors).

3. Bu çalışma, intihal tarama programı kullanılarak intihal taramasından geçirilmiştir (This article was screened for potential plagiarism using a plagiarism screening program). 